Arab Univ. J. Agric. Sci., Ain Shams Univ., Cairo, 13(2), 367 - 383, 2005

\title{
QUALITY EVALUATION OF BEEF STEAKS WITH EDIBLE COATING DURING DEEP - FRYING
}

[23]

\author{
Nessrien, M.N.Yasin ${ }^{1}$; Hanan, M.A. Al-Sayed ${ }^{1}$ and \\ Salwa, M. Abo-El-Fetoh ${ }^{1}$
}

\begin{abstract}
Quality of fried beef steaks coated with sodium alginate, carrageenan and carboxy methyl cellulose (CMC) at concentrations $0.3,0.6$ and $0.9 \%$ as well as oils used for frying were evaluated after several frying times (1, 3, 5 and 7 times). Weight loss, shrinkage, moisture loss and final lipid content of control sample were sharply increased after the first time of frying compared to other treatments. The lower reduction in weight loss was achieved in fried beef steaks coated with CMC at concentration of $0.9 \%$. Samples coated with $0.9 \%$ carrageenan caused a considerable decrease especially in shrinkage and moisture loss followed by samples coated with $\mathrm{CMC}$ and then those coated by sodium alginate at different concentrations. The same treatment $(0.9 \% \mathrm{CMC})$ showed the lower value of final lipid content. There were significant $(\mathrm{p}<0.01)$ decremental patterns in all of sensory attributes (appearance, flavor, color, juiciness, mouth feel, texture and overall acceptability) of fried beef steaks during subsequent frying times for all treatments. Less rates of these deterioration were appeared in CMC samples with different concentrations followed by samples coated with $0.3 \%$ and $0.6 \%$ of sodium alginate. Progressive rise in acid value of frying oils was especially found in control sample during different frying times, on the other hand the low rate of increase was appeared in sample coated with $0.3 \%$ and $0.6 \%$ sodium alginate. The higher values of $\mathrm{K}_{232}$ appeared in control sample followed by $0.9 \%$ CMC but lower value recorded by oil used for frying beef steaks coated with $0.3 \%$ and $0.6 \%$ of sodium alginate after 5 times of frying. The same behavior was appeared in $\mathrm{K}_{270}$ determination except there was decrement pattern in this criteria by increasing frying times especially from 5 to 7 times of frying in control and coated samples with $0.3 \%$ and $0.6 \%$ of carrageenan. The highest value of refractive index of fried oil was in control sample followed by coated sample with $0.9 \%$ sodium alginate after 7 times of frying. However, the lower value was in coated sample with $0.6 \%$ carrageenan under the same conditions. It is cleared to know that, the viscosity of oil which used for frying control sample was lower than that of other treatments during various frying times. Data revealed that the color index (oil deterioration) increase as the concentration of different edible coatings of beef steaks and number of frying increased.
\end{abstract}

1- Food Science and Technology Departement, Fac. of Agric., Ain Shams Univ., Shoubra El- Kheima, Cairo, Egypt 
Key words: Edible coating, Beef steaks, Frying oil, Physical characteristics and Quality

\section{INTRODUCTION}

With the increase in consumption of fast and snack foods, deep- fat/oil fried foods have become a major part of diet (Mittal and Zhang 2000). Deep -frying is a popular food preparation procedure. Frying oil imparts desirable flavor and textural properties to food. Extensive use of oil, however, leads to the release fatty acids, oxidative volatiles and polymer by hydrolysis, oxidative and thermal reaction, respectively. Upon generation of degradative surfactants and volatile chemicals, foaming and smoking of the oil ensue, respectively. In addition, uptake of undesirable flavors and excess absorption of oil by the product also occurs. Consequently, such used frying oil must be discarded and replaced with fresh oil (Holownia et al 2000).

Precooked meat products are susceptible to lipid oxidation, which leads to rapid development of rancid. Moisture loss is a critical factor affecting the quality and shelf - life of precooked meats. As consumer demand for more convenience food has grown rapidly, much effort has been devoted to improve quality of precooked meat products. Among many techniques to control the quality of precooked meats, appropriate packaging is a common solution for maintaining precooked meat quality (Wu et al 2000).

Edible films prepared from polysaccharide, protein and lipid materials may serve as oxygen and / or moisture barriers and can be used to maintain food quality, Wu et al (2001). Hsia et al (1992) and Wu et al (2000) reviewed the functionali- ty of hydrocolloids in batter coating system and in meat products. However, the application of edible/biodegradable coatings and films on precooked meat products has not been as extensively studied as has their applications on fresh and frozen meat products. Besides their barrier properties, edible films and coatings can act as carriers for functional food additives such as antioxidants (Cuppett, 1994).

Food hydrocolloids with thermal gelling or thickening properties have been widely investigated. Adding food hydrocolloids as dry ingredients is a practical way to lower oil uptake of deep- fat fried foods since the addition does not change conventional production procedures. Edible coatings at the surface of foods are possible. However, in this case dipping solutions or sprayed on coatings must be prepared separately (Funami et al 1999). Sodium carboxymethylcellulose which is more commonly called cellulose gum or CMC is available in a variety of types based on particle size, degree of substitution, viscosity and hydration characteristics. Solutions of the gum exhibit pseudoplasticity, generally used to thicken, suspend, stabilize, gel and modify flow characteristics of aqueous solutions or suspensions (Dziezak- Judie, 1991).

Carrageenan is sulfated / linear polysaccharides which extract from certain red marine algae (Sharma, 1981 and Rhidout et al 1996). Carrageenan has been used for making dessert, jellies for controlling texture and for water holding in processed meat products. Rheological and thermal properties are important 
function properties for the utilization of gelling agents (Nishinari et al 1996). Alginates are extracted from the class of brown seaweed known as phoreophyceae. Alginates have found use in a variety of products. Most often alginates are used for thickening, emulsion, stabilization and gelation (Dziezak- Judie, 1991).

Therefore, the present investigation was carried out to evaluate several beef steaks coating agents with different concentrations and their effects on both frying oils and the obtained fried beef steaks qualities.

\section{MATERIAL AND METHODS}

\section{1- Materials}

1-1. Coating agents including carrageenan, sodium alginate were obtained from Sigma Chemical Co. USA and carboxymethylcellulose sodium salt was obtained from El - Nasr - Pharmaceutical Chemical Company, Cairo, Egypt.

1-2. Beef steaks (from rump cut with total area $36.5 \mathrm{~cm}^{2}$ and $2 \mathrm{~cm}$ thickness), wheat flour, seasoning and sunflower oil (its characteristics were: acid value $0.50 \mathrm{mg}$ alcohol. $\mathrm{KOH} / \mathrm{g}$ oil, refractive index 1.4700 and viscosity 0.899 poise at shear rate $9 \mathrm{~S}^{-1}$ ) were purchased from the local market.

\section{2- Methods}

\section{2-1. Edible coating preparation}

Edible coatings (carragenan, sodium alginate and carboxymethylcellulose) were first dispersed in hot water $\left(90^{\circ} \mathrm{C}\right)$.
Cold water then added to these solutions with continuous agitation to give a final concentration $0.3 \%, 0.6 \%$ and $0.9 \%$ for all agents.

\section{2-2. Beef steaks preparation}

Beef steaks were dipped for a few seconds into the edible coating solutions followed by drying for $5 \mathrm{~min}$ before breading with wheat flour and were fried at $174{ }^{\mathrm{O}} \mathrm{C} / 3 \mathrm{~min}$ in fresh oil. The following studies were done with triplicate samples for each trial. The beef steaks were taken after the first frying time. The different treated oil was used in frying by 7 times, the oil samples were analyzed after 1, 3, 5 and 7 times of frying.

\section{2-3 Product evaluation}

\section{2-3-1 Weight loss}

Weight loss was determined as the method mentioned by Bigner-George and Berry (2000).

\section{2-3-2 Shrinkage}

The reduction in beef steaks diameter (shrinkage) was determined as described by Louis et al (1987) with a ruler using the following equation:

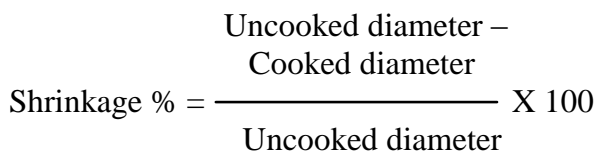

\section{2-3-3 Moisture loss}

Moisture content of samples was determined using A.O.A.C. (1990). Moisture loss according to Wu et al (2000) was calculated as: 
Initial moisture content (before frying) - final moisture content (after frying)

Moisture loss \% =

$X 100$

Initial moisture content

\section{2-3-4. Final lipid}

A soxhelt extraction (A.O.A.C., 1990) of the dried fried beef steaks was utilized.

\section{2-3-5. Sensory evaluation}

A multiple comparison test was conducted for sensory evaluation of fried beef steaks (Larmond, 1970).

Ten panelists were receiving samples to compare for appearance, flavor, color, juiciness, mouth feel, texture and overall acceptability. They have been given a control sample, marked $\mathrm{R}$, to which they were to compare each sample showing whether it is better than, comparable to, or inferior to the reference. Then they marked the amount of difference that exists (none, slight, moderate, much, extreme). The ratings were given numerical values 1 to 9 by the person on analyzing the results with (no difference) equaling 5, (extremely better than R) equally 9, and (extremely inferior to R) equally 1 .

\section{2-4. Oil evaluation}

\section{2-4-1. Refractive index}

Refractive index of oil was measuring according to the method given by A.O.A.C. (1990) using the refractometer type Carlzeiss Jena 264929.

\section{2-4-2. Acid value}

Free Fatty Acids (FFA) were determined according to the method that described in A.O.A.C. (1990). The results were calculated as $\mathrm{mg}$ alcoholic $\mathrm{KOH} / \mathrm{g}$ of oil.

\section{2-4-3. UV}

Extinction coefficients were measured $\left(\mathrm{K}_{270}\right.$ and $\left.\mathrm{K}_{232}\right)$ using a uv spectrophotometer (Hewlett Packard, Model 8452 A) according to Aranzazu et al (2001).

\section{2-4-4. Viscosity}

The investigated oil samples were introduced into the $\left(\mathrm{S}_{1}\right)$ cylinder of Rotational Viscometer (Rheotest 2 Germany) and measuring the shear stress developed at shear rates of 3, 5.4, 9, 16.2, 48.6 and $81 \mathrm{Sec}^{-1}$ respectively. The viscosity was calculated according to Krumel and Sarkar, (1957) as follows:

$$
\begin{aligned}
& \eta=\tau / \gamma \\
& \tau=z . \alpha
\end{aligned}
$$

Where: $\eta=$ viscosity (poise).

$\tau=$ shear stress $\left(\right.$ dynes $\left./ \mathrm{cm}^{2}\right)$.

$\mathrm{z}=$ cylinder constant.

$\alpha=$ read out value

$$
\gamma=\text { shear rate }\left(\sec ^{-1}\right)
$$

\section{2-4-5. Color index}

Color index was measured according to A.O.A.C. (1990) using spectrophotometer (Hewlett Packard, Model 8452 A) and absorbance was read at the following wavelengths 460, 550, 620 and $670 \mathrm{~nm}$. 
The spectrophotometer color index was calculated from the following equation:

Color index $=1.29\left(A_{460}\right)+69.7\left(A_{550}\right)+$
$41.2\left(A_{620}\right)+56.4\left(A_{670}\right)$.

\section{2-5 Statistical analysis}

The data were subjected for analysis of variance and Duncan's Multiple Comparison Test analyzed according to User's Guide of Statistical Analysis System (SAS, 1996) at the computer center of Faculty of Agriculture Ain Shams University.

\section{RESULTS AND DISCUSSION}

\section{Physical characteristics of fried beef steaks coated with different concen- trations of edible coatings}

As shown in Table (1) it could be proved that, there were significant $(p<0.01)$ effects of some edible coatings and concentrations on weight loss, shrinkage, moisture loss and final lipid of fried beef steaks. These parameters were significantly $(\mathrm{p}<0.01)$ reduced gradually when increase the concentrations of all types of edible coatings. From this table it could be noticed that, weight loss, shrinkage and moisture loss of control sample were sharply increased after the first time of frying when compared with other treatments during the same frying time. The lower reduction in weight loss was achieved in fried beef steaks coated with carboxy methyl cellulose (CMC) at concentration of $0.9 \%$, since the weight loss value reduced by $28.289 \%$ (from $43.317 \%$ for control to $31.063 \%$ ), these results are agreed with those obtained by Wu et al (2001). The same treatment showed the lower value of final lipid $(6.367 \%)$, these results coincided with
Williams and Mittal, (1999) who found that many hydrocolloids, long - chain polymers, especially cellulose derivatives, form gels which can be used in frying to reduce oil absorption. This should be attributed to not only the increase in water holding but also the structural oil barrier formation and all these effects of that barrier associated with its thermal gelation during deep - fat frying. Whereas, the samples coated with $0.9 \%$ carrageenan caused a considerable decrease especially in shrinkage and moisture loss (29.937\% and $35.220 \%$, respectively followed by CMC samples and alginate samples at different concentrations, these results are similar to that reported by $\mathbf{W u}$ et al (2000) who demonstrated that coating with carrageenan reduced moisture loss in precooked beef patties. Also, they found that coating was effectively retarded lipid oxidation in the patties.

\section{Sensory attributes of fried beef steaks with different concentrations of edible coatings}

As seen in Table (2), there were significant $(\mathrm{p}<0.01)$ decremental patterns in all tested sensory characteristics during different frying times. Also, after the first time of frying, there were significant $(\mathrm{p}<0.01)$ differences between samples. All treated beef steaks suffered from a concomitant deterioration in all sensory properties by increasing the frying times especially in control sample. Less rates of these deterioration were appeared in CMC samples with different concentrations when compared to other treatments followed by samples coated with $0.3 \%$ and $0.6 \%$ of sodium alginate. This is due to the presence of a gum constituent or 
Table 1. Quality characteristics of coated beef steaks with sodium alginate, carrageenan and carboxymethylcellulose as coating agents

\begin{tabular}{|ccccc|}
\hline & \multicolumn{4}{c|}{ Quality characteristics } \\
\cline { 2 - 5 } Treatments & $\begin{array}{c}\text { Weight loss } \\
\%\end{array}$ & $\begin{array}{c}\text { Shrinkage } \\
\%\end{array}$ & $\begin{array}{c}\text { Moisture loss } \\
\%\end{array}$ & $\begin{array}{c}\text { Final lipid } \\
\%\end{array}$ \\
\hline Control & $43.317^{\mathrm{A}}$ & $53.977^{\mathrm{A}}$ & $59.953^{\mathrm{A}}$ & $17.843^{\mathrm{B}}$ \\
Sodium alginate & & & & \\
$0.3 \%$ & $37.807^{\mathrm{D}}$ & $44.927^{\mathrm{C}}$ & $55.297^{\mathrm{B}}$ & $14.647^{\mathrm{G}}$ \\
$0.6 \%$ & $37.137^{\mathrm{E}}$ & $43.227^{\mathrm{E}}$ & $54.117^{\mathrm{C}}$ & $15.063^{\mathrm{F}}$ \\
$0.9 \%$ & $35.430^{\mathrm{G}}$ & $38.510^{\mathrm{G}}$ & $46.310^{\mathrm{E}}$ & $15.393^{\mathrm{E}}$ \\
Carrageenan & & & & \\
$0.3 \%$ & $40.883^{\mathrm{B}}$ & $45.837^{\mathrm{B}}$ & $49.287^{\mathrm{D}}$ & $18.110^{\mathrm{A}}$ \\
$0.6 \%$ & $36.480^{\mathrm{F}}$ & $36.810^{\mathrm{I}}$ & $36.313^{\mathrm{H}}$ & $17.783^{\mathrm{B}}$ \\
$0.9 \%$ & $33.377^{\mathrm{H}}$ & $29.937^{\mathrm{J}}$ & $35.220^{\mathrm{I}}$ & $16.897^{\mathrm{C}}$ \\
Carboxymethylcellulose & & & \\
$0.3 \%$ & $40.893^{\mathrm{B}}$ & $43.947^{\mathrm{D}}$ & $44.537^{\mathrm{F}}$ & $15.697^{\mathrm{D}}$ \\
$0.6 \%$ & $38.587^{\mathrm{C}}$ & $41.003^{\mathrm{F}}$ & $39.663^{\mathrm{G}}$ & $12.017^{\mathrm{H}}$ \\
$0.9 \%$ & $31.063^{\mathrm{I}}$ & $38.143^{\mathrm{H}}$ & $35.960^{\mathrm{H}}$ & $6.367^{\mathrm{I}}$ \\
\hline
\end{tabular}

A, B,.....Means with the same superscript letter within the same parameter are not significantly different $(\mathrm{p}>0.01)$.

gum additive in the food which dissolves throughout meat during thermal processing and gel forms during cooling enhancing texture properties of product and improving product juiciness (Defreitas et al 1997)

In conclusion, we could say the carboxy methyl cellulose with different concentrations $(0.3,0.6$ and $0.9 \%)$ improved the characteristics (juiciness, mouth feel, texture and overall acceptability) during incremental the frying time.

\section{Effect of edible coatings and concen- trations on quality characteristics of frying oil}

\subsection{Chemical properties}

\subsubsection{Acid value}

Table (3) indicated that, there was significant $(p<0.01)$ effect of coating on acid value of frying oil after the first time of frying. These results could be attributed to the higher temperature in frying media that accelerate the thermal 
Arab Univ. J. Agric. Sci., 13(2), 2005 
Nessrien; Hanan and Salwa

Arab Univ. J. Agric. Sci., 13(2), 2005 
Arab Univ. J. Agric. Sci., 13(2), 2005 
oxidation and polymerization. Also, it could be noticed that, there was significant $(\mathrm{p}<0.01)$ increase in acid value by increasing of concentrations of such edible coatings.

With regard to Table (3), the acid value of frying oil after one time ranged between $0.580-0.477 \mathrm{mg} \mathrm{KOH} / \mathrm{g}$ oil for different treatments. Progressive rise in acid value was especially found in control sample during different frying times. The low rate of increase was appeared in samples coated with $0.3 \%$ and $0.6 \%$ of sodium alginate, for example, it reached 0.520 and $0.577 \mathrm{mg} \mathrm{KOH} / \mathrm{g}$ oil , respectively after 7 times of frying. These results support the role of edible film to slow migration of polar agents (water and acetic acid) from the product to the oil that in turn have been shown accelerate hydrolysis of fat (Holownia et al 2000).

\subsubsection{UV determination}

The specific extinction at $232 \mathrm{~nm}$ wavelength, $\mathrm{K}_{232}$, is related to the primary oxidation rate of fats while $\mathrm{K}_{270}$ is related to the secondary oxidation rate (Ranalli et al 1998). From Table (3) it could be noticed that the higher values were obtained for $\mathrm{K}_{232}$ values than for $\mathrm{K}_{270}$ at the same frying time indicating a trend toward greater autoxidation by increasing frying times. Frying oil of beef steaks coated by $0.3 \%$ and $0.6 \%$ of sodium alginate showed lower incremental pattern in $\mathrm{K}_{232}$ when compared with other treatments (it was 2.966 and 2.986, respectively after 5 times of frying). The higher values appeared in control samples followed by samples coated by $0.9 \% \mathrm{CMC}$ during subsequent frying times. For example, it reached 3.913 and 3.912, respectively after 5 times of frying.
The same behavior was appeared in $\mathrm{K}_{270}$ determination except there was decrement pattern in this criteria by increasing frying times especially from 5 to 7 times of frying in control and samples were coated with $0.3 \%$ and $0.6 \%$ of carrageenan. This is because of the rate of formation of secondary products from oil oxidation such as peroxides during subsequent frying times is less than the rate of its degradation (Mohamed, 1991)

\subsection{Physical properties}

\subsubsection{Refractive index}

Refractive index of fats and oils is an important characteristic because of the ease and speed with which it can be determined precisely, the small quality of sample needed and its relationship to structure.

Table (3) cleared that, the refractive index was ranged between 1.47001.4724 after the first time of frying then continuously increased by increasing of frying times. It is of interest to found that, the highest value was in control sample (1.4740) followed by the samples coated with $0.9 \%$ sodium alginate (1.4739) after 7 times of frying. However, the lower value was in samples coated with $0.6 \%$ carrageenan (1.4719) under the same conditions.

The increase in refractive index of sunflower oil could be attributed to the polymerization and formation of high molecular weight components. These data are in agreement with those obtained by Mohamed, (1991). 
Fig. 1. Viscosity of frying oil of coated beef steak with different concentrations of edible coatings as affected by frying times (1, 3, 5 and 7 times) 
Nessrien; Hanan and Salwa

Fig. 1. Cont.

Arab Univ. J. Agric. Sci., 13(2), 2005 


\section{Carboxymethylcellulose}

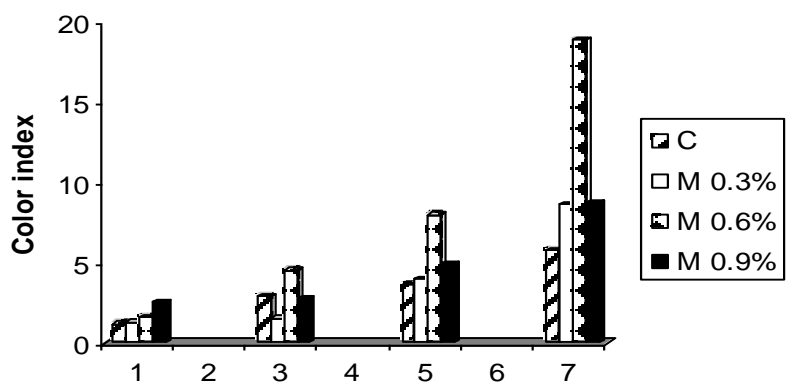

Carrageenan

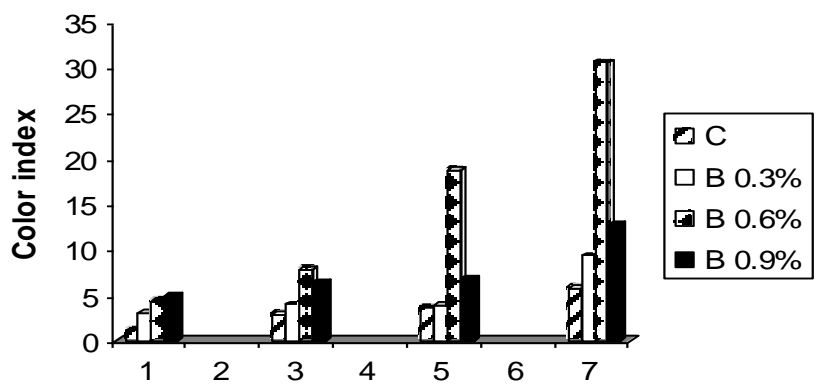

Sodium alginate

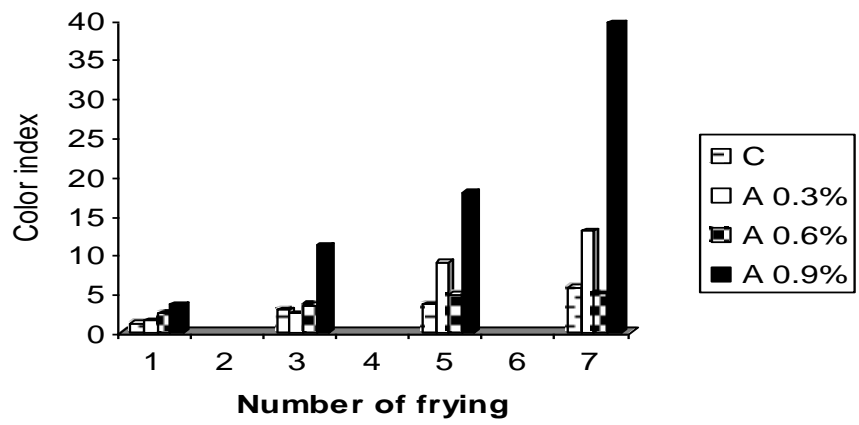

Fig. 2. Color index of fried oils of coated beef steaks with different concentrations of edible coatings as affected by frying times 


\subsubsection{Viscosity}

The viscosity of oils used for frying beef steaks with edible coatings was measured at different shear rates at $25^{\circ} \mathrm{C}$ and the results are illustrated in Fig. (1). Increasing of shear rate from 3 to $81 \mathrm{~S}^{-1}$ resulted in a significant decrease of viscosity for various oils which used for frying beef steaks with edible coatings during number of frying. It is cleared to know that, the viscosity of oil which used for frying control sample was lower than that of other treatments during various frying times. This is due to the rheological properties and adhesion characteristics of those hydrocolloids which increased the adhesion and apparent viscosity of product as reported by Hsia $\boldsymbol{e t}$ al (1992). In all oils samples, there were significant decremental patterns in its viscosity. This may be accounted for the moisture that migrated from the product to the oil during subsequent frying times. These results are in agreement with these obtained by Holowina et al (2000).

\subsubsection{Color index}

Fig. (2) shows the photometric color indices of sunflower oil during deep frying of edible coated beef steaks. Data revealed that the color index (oil deterioration) increased as increased the concentration of different edible coatings of beef steaks and number of frying. This increase was a combined result of oxidation and polymerization of the unsaturated fatty acids and other chemical changes that developed during frying times. Opposite of that trend both carrageenan and carboxy methyl cellulose increased color index at $0.6 \%$ then decreased at $0.9 \%$. From this Fig. (2) it could be found that, sodium alginate as coating agent is more effect in color index of frying oils compared with carrageenan and carboxy methyl cellulose. These results cleared the effect of such edible films on color index which is due to increasing browning of oil through Millard reactions (Holowina et al 2000).

\section{CONCLUSION}

Edible coatings used in this study differed in limiting weight loss, shrinkage, moisture loss and final lipid depending upon the coatings composition. Both of carrageenan and $\mathrm{CMC}$ at $0.3 \%$ and $0.6 \%$ were more effective in controlling moisture loss than sodium alginate. Whereas, coating with $0.9 \%$ carrageenan decreased shrinkage of steaks. The CMC coating improved sensory characteristics of beef steaks at different used concentrations. However, coatings with sodium alginate $(0.3 \%$ and $0.6 \%)$ were controlling lipid oxidation. All edible coatings generally increased the viscosity of frying oils compared with control sample. Frying oils of coated samples with sodium alginate had higher values of color index (more oil deterioration in color) on opposite of that behavior, CMC samples showed less values of that criteria.

\section{REFERENCES}

A.O.A.C. (1990). Official Methods of Analysis: Association of Official Analytical Chemists. 15th (Ed). Washington. DC.

Aranzazu, G.; M. Brenes; M.J. Moyano; J. Alba and P. Garcia (2001). Improvement of compound content in virgin olive oils by using enzymes during maloxation. J. Food Engineering 48: 189194. 
Binger-George, M.E. and B.W. Berry (2000). Thawing prior to cooking affects sensory shear force and cooking properties of beef patties. J. Food Sci., 65: 2-8. Cuppett, S.L. (1994). Edible coatings as carriers of food additives, fungicides and natural antioxidants. In: Krochta, J.M.; E.A. Baldwin; M. Nisperos - Carriedo, (Ed). Edible Coatings and Films to Improve Food Quality. Lancaster, P.: Technomic Publishing Company. Inc. pp. 121-137. Cited from: Wu et al 2001. Defreitas, Z; J.G. Sebranek; D.G. Olsan and J.M. Carr (1997). Carrageenan effects on thermal stability of meat proteins. J. Food Sci., 62: 539-543.

Dziezak-Judie, D. (1991). A Focus on gums. Food Tech. 45(3): 116-128.

Funami, T.; M. Funami; T. Tawada and Y. Nakao (1999). Decreasing oil uptake of doughnuts during deep - fat frying using curdlan. J. Food Sci., 64: 883-889.

Holownia, K.I.; M.S. Chinnan; M.C. Erickson and P. Mallikarjunan, (2000). Quality evaluation of edible film-coated chicken strips and frying oils. J. Food Sci., 65: 1087-1090.

Hsia, H.Y.; D.M. Smith and J.F. Steffe (1992). Rheological properties and adhesion characteristics of flour - based batters for chicken nuggets as affected by three hydrocolloids. J. Food Sci. 57: 16$18 \& 24$.

Krumel, K.L. and N. Sarkar (1957). Flow properties of gums useful to the food industry. Food Tech. 11(4): 36-44. Larmond, E. (1970). Methods for Sensory Evaluation of Food. Pub. No. 1284, pp. 19-24 \& 40-43. Canada Dept. of Agric., Ottawa. Ontario, Canada.

Louis, L.Y.; C.E. Lyon; G.K. Searcy and R.L. Wilson (1987). Influence of sodium tripolyphosphate and sodium chloride on moisture retention and textural characteristics of chicken breast meat patties. J. Food Sci., 52 : 571.

Mittal, G.S. and J. Zhang (2000). Use of artificial neural network to predicate temperature, moisture and fat in slabshaped foods with edible coatings during deep - fat frying. J. Food Sci., 65: 978983.

Mohamed, M.M.M. (1991). Evaluation of Certain Oils for Food Utilization. $\mathrm{Ph}$. D. Thesis, Fac, Agric., Ain Shams Univ., Cairo, Egypt. pp. 36 \& 118.

Nishinari, K.; M. Watase; M. Rinaudo and M. Milas (1996). Characterization and properties of gellan - K- carrageenan mixed gels. Food Hydrocolloids 10: 277 283.

Ranalli, A.; G. De Mattia and M.L. Ferrante (1998). The characteristics of percolation olive oils produced with a new processing enzyme aid. J. Food Sci., Tech. 32: 247-258.

Rhidout, M.J.; S. Garza; G.J. Brownsey and V.J. Morris (1996). Mixed iotaKoppa carrageenan gels. International J. Biological Marcromolecules 18: 5-8. SAS, (1996). Statistical Analysis System. SAS User's Release 6.04 Edition Statistics SAS institute Inc. Editors, CARY, NC., USA.

Sharma, S.C. (1981). Gums and hydrocolloids in oil water emulsions. Food Tech. 35(1): 59-67.

Williams, R. and G.S. Mittal (1999). Low - fat fried foods with edible coatings: Modeling and Simulation. J. Food Sci., 64: 317-322.

Wu, Y.; J.W. Rhim; C.L. Weller; F. Hamouz; S. Cuuppet and M. Schnepf (2000). Moisture loss and lipid oxidation for precooked beef patties stored in edible coatings and films. J. Food Sci., 65: 300304. 
Wu, Y.; C.L. Weller; F. Hamouz; S. Cuppet and M. Schnepf (2001). Moisture loss and lipid oxidation for pre cooked ground - beef patties packaged in edible starch - alginate- based composite films. J. Food Sci., 66: 486-493.

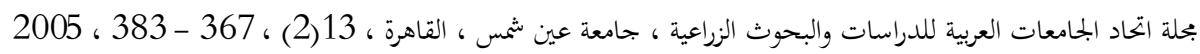
تقييم جودة شرائح اللحم المقلي و المغطي بأغطية قابلة للأكل

نسرين محمد نبيه يسن 1 - حنان محمد عبده السيد1 - سلوي محمود أبو الفتوح1 1 1 - قسم علوم الأغذيه - كلية الزراعه - جامعة عين شمس - شبرا الخيمة - القاهرة - مصر

الفم و القو ام و التقبل العام) لشر ائح اللحم المقلي بزيادة أوقات القلي في كل المعاملات. وقد وجد أن أقل معدلات التدهور في الصفات الحسيه كانت للعينات المغطاه

بالتركيز ات المختلفه من كربوكسي ميثيل

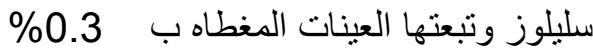
و0.6\% ألجينات الصوديوم. و قد وجد زيادة ملحوظه في رقم الحامض للزيت المستخدم في القلي لعينة الكنترول خلال مر ات القلي القي ومن جهة أخري ظهر أقل معدل للزياده لرقم الحامض للعينات المغطاه ب ب و0.6\% ألجينات الصوديوم. سجلت عينات الكنترول أعلي قيمه ل K يتبعها العينه المغطاه ب 0.9\% كربو كسي ميثيل سليلوز

و لكن الزيت المستخدم في قلي العينات المغطاه ب 0.3\% و0.6\% ألجينات الصوديوم سجل أقل القيم بعد خمس قليات.

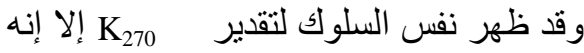
حدث إنخفاض في هذا التقدير بزيادة فترات القلي من 5 ألي 7 درات في عينات الكنترول

$$
\text { قدرت جودة شر ائح اللحم المقلي }
$$
و المغطي ب (ألجينات الصوديوم وكار اجينان وكربوكسي ميثيل سليلوز) عند تركيز ات 0.3 و0.6\% و0.9\% و كذللك زيت القلي خلال مرات القلي ( 1 و3 و5 و 7). وجد أن ؤن وكأن

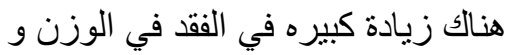
الإنكماش و فقد الرطوبه و المحتوي الليبيدي

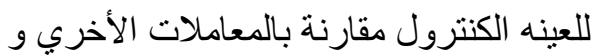
ذللك بعد أول مره قلي. أعطت شر ائح اللحم المقلي و المغطي بكربوكسي مينيل سليلوز عند تركيز 0.9\% أقل إنخفاض في الفقد في الوزن حيث بلغت 28.289\% \% سجلت شر ائح اللحم المغطي ب ب 0.9\% كار اجينان إنخفاض في الإنكماش و فقد الرطوبه ثم تبعتها العينات المغطاه ب كربوكسي ميثيل سليلوز و ألجينات الصوديوم و نفس المعامله (0.9 كربو كسي ميثيل سليلوز) أظهرت أقل محتوي ليبيدي. هناك إنخفاض معنوي ملحوظ في الخصائص الحسيه (المظهر العام

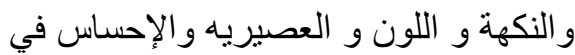




\begin{abstract}
نفس الظروف. و من الو اضح تميز لزوجة عينات الزيت المستخدم لقلي عينة الكنترول بالإنخفاض مقارنة بالمعاملات الأخري أثناء

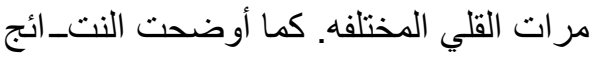
زيادة معامل لون (تدهور الزيت) بزيادة تركيز الأغطيه المختلفه لقطع اللحم و كذللك

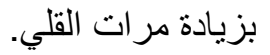

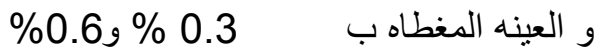
كار اجينان. و قد لوحظ أن معاملة الكنترول كانت لها أعلي قر اءه لمعامل الإنكسار و و تبعتها العينات المغطاه ب 0.9\% ألجينات الصوديوم بعد 7 مر ات قلي. في حين سجلت

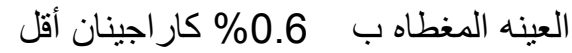
معامل أنكسار تحت

تحكيم: أ.د رمضنان محمد محمود أ.د حمدى عبد اللطيف رمفن مجدان 